\title{
Development and quality assessment of honey nut drink
}

\author{
Abu Saeid*, Md. Atikur Rahman, Md. Rohit Hasan Utsob, Md. Uzzal Hosen, Md. Morshedul Islam, Md. Saiful \\ Islam and Bishwajit Halder
}

Department of Food Engineering, NPI University of Bangladesh, Manikganj, Bangladesh.

*Corresponding Author Email: saeidfpp.hstu@gmail.com

\section{Doi: 10.2478/mjhr-2021-0002}

\section{Abstract:}

The objective of this study was to standardize the formulation of honey nut drink, to assess the quality parameters like pH, brix, acidity, brix acid ratio and sensory characteristics of formulated honey nut drink under 12 days of storage at ambient temperature $\left(32 \pm 2^{\circ} \mathrm{C}\right)$. The pH values varied from 3.5 to 3.9 during storage. The brix found in three different products ranged from 7 to $13 \%$. The acidity possesses during the entire storage period between 0.16 to $0.32 \%$. The brix acid ratio higher found in product 2 (59.99) and lower in product 3 (35.0) under storage. The sensory profile of three different formulation was evaluated in terms of color, flavor, taste and overall acceptability. Among the three-products formulation product 1 retained better quality followed by product 3 and product 2 considering $\mathrm{pH}$, brix and acidity percentage although after increasing time of storage their value also increased. The sensory profile of product 3 found in much better score followed by the product 1 and product 2 which are significantly different $(\mathrm{p} \leq 0.05)$. In conclusion, both formulation of product 1 and product 3 could be produced in commercial purpose.

Keywords: Honey nut drink; pH; brix; Acidity and sensory characteristics.

\subsection{Introduction}

Continuous development of new functional foods is the response of science and industry to the increased consumer awareness regarding health and the role of foods for improving quality of life [1]. Long known for the benefits of honey and nut for becoming popular as part of a healthy diet and new products emerge at the functional food market. Honey is a natural substance produced, when the nectar and sweet deposits from plants are gathered, modified and stored in the honeycombs by honeybees of the genera Apis and Meliponini [2]. Honey contains about 180 types of different compounds, including water, sugars, free amino acids, proteins, enzymes, essential minerals, vitamins, and various phytochemicals [3]. Its content in flavonoids and phenolic acids [4] plays a key role on human health, thanks to the high antioxidant and anti-inflammatory properties that they exert. Honey possesses antimicrobial capacity and anticancer activity against different types of tumors, acting on different molecular pathways that are involved on cellular proliferation. In addition, an antidiabetic activity has also been highlighted, with the reduction of glucose, fructosamine, and glycosylated hemoglobin serum concentration. Honey exerts also a protective effect in the cardiovascular system [5], where it mainly prevents the oxidation of low-density lipoproteins, in the nervous system, in the respiratory system against asthma and bacterial infections, and in the gastrointestinal system. A beneficial effect of honey can also be demonstrated in athletes [6]. On the other hand, Nuts (tree nuts and peanuts) are nutrient dense foods with complex matrices rich in unsaturated fatty and other bioactive compounds: high-quality vegetable protein, fiber, vitamin (e.g., folic acid, niacin, tocopherols, and vitamin B6), minerals such as calcium, magnesium, potassium, tocopherols, phytosterols, and phenolic compounds $[7,8]$.

By virtue of their unique composition, nuts are likely to beneficially impact health outcomes. Epidemiologic studies have associated nut consumption with a reduced incidence of coronary heart disease and gallstones in both genders and diabetes in women. Limited evidence also suggests beneficial effects on hypertension, cancer, and inflammation. Interventional studies consistently show that nut intake has a cholesterol-lowering effect, even in the context of healthy diets, and there is emerging evidence of beneficial effects on oxidative stress, Inflammation, and vascular reactivity. Blood pressure, visceral adiposity and the metabolic syndrome also appear to be positively influenced by nut consumption [9]. Honey can also b e commercially utilized in the manufacture of various fruits and vegetables preserves in place of white sugar or jaggery such products may be honey squash with lemon or mango, honey jam, honey candy, honey chocolate, honey jelly, honey murabba, honey petha, honey toffee etc. Honey has gained success about $2-3 \%$ inclusion in prune juice. It also be used as $4 \%$ in apple juice for the clarification purpose. It used as a sweetening agent in tea [10]. Nut could be used in Beer preparing as a functional drink [11]. Four kind of nut paste utilize in bread to study the morphogeometric and textural characteristics [12]. In Western countries nuts are consumed as snacks, desserts or part of a meal, and are eaten whole (fresh or roasted), in spreads (peanut butter, almond paste), as oils or hidden in commercial products, mixed dishes, sauces, pastries, ice creams and baked goods [9]. However, to the best of our knowledge no such work found in the literature. This is why, an attempt was taken to develop a new functional drink name honey nut drink. The objective of this study was to standardize the formulation of honey nut drink, to assess the quality parameters and sensory characteristics under twelve days of storage at ambient temperature.

\subsection{Materials and Method}

\subsection{Materials}

\subsubsection{Sample collection and preparation}

Honey and nut ware purchased from the local market of Dhaka city, Bangladesh. In laboratory, nut was dried in oven dryer and powder were made using grinder and stored in airtight amber bottle for further analysis.

\subsubsection{Chemical and reagents}

Sugar, aspartame, citric acid, sodium benzoate, potassium sorbet, vitamin c, salt, food grade color, and flavors etc. were used in this study.

\subsection{Method}

The formulation of honey nut drink (Table 1) and manufacturing process of honey nut drink has shown in Figure 1. 


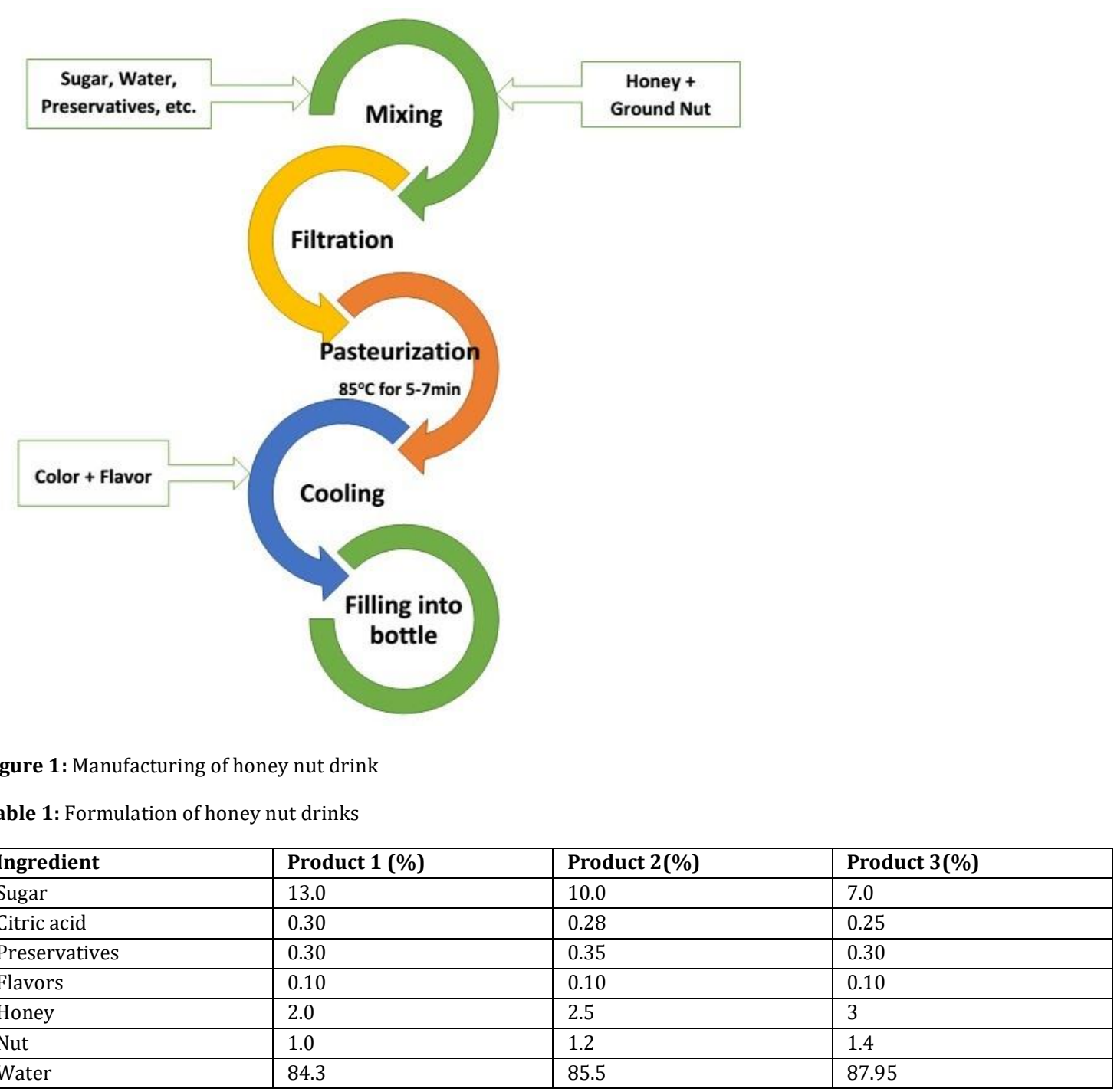

\subsubsection{Determination of Titratable acidity}

Titratable acidity was determined according to the method reported by Teka [13] with few modifications. Five mL of sample was diluted to $95 \mathrm{~mL}$ of deionized-distilled water. $10 \mathrm{~mL}$ diluted sample was taken in conical flask. After that, 2-3 drops of phenolphthalein indicator was added to the flask. Then the solution was titrated by $0.1 \mathrm{~N} \mathrm{KOH}$ solution until the end point is reached. The acid content of the sample was calculated based on the volume of $0.1 \mathrm{~N} \mathrm{KOH}$ used for neutralizing the acid content in the sample and multiplying by a correction factor of 0.064 to estimate titratable acidity as percentage of citric acid. The titratable acidity was calculated using the following equation:

$\%$ Acidity $=\frac{\mathrm{mL} \text { of } \mathrm{KOH} \times \text { Normality of } \mathrm{KOH} \times \text { Acid factor }}{\mathrm{mL} \text { of sample taken }} \times 100$

\subsubsection{Determination of Brix and brix acid ratio}

The brix percentage of the honey nut drink were determined by using a handheld refractometer (Model: HT119-ATC). Brix acid ratio was calculated using brix divided by acidity value.

\subsubsection{Determination of $\mathrm{pH}$}

$\mathrm{pH}$ meter (Model: LMPH-10) was used to determine the $\mathrm{pH}$ value of the sample. The $\mathrm{pH}$ meter was standardized by using buffers of $\mathrm{pH} 7.00$ and $4.00 \mathrm{prior}$ to recording $\mathrm{pH}$ of the samples.

\subsubsection{Sensory Evaluation}

Sensory evaluation was carried out on 12 days of storage. Fifteen panel members were selected from the University community. Randomly, the samples were presented. Honey nut drink were evaluated organoleptically for color, flavor, taste and overall acceptability, according to the hedonic scale of nine points (9-like extremely to 1- dislike extremely), as reported by Roy et al., [14].

\subsubsection{Statistical Analysis}

Data were statistically analyzed using the statistical software R (windows version 3.6.1). All results were measures triplicate for each sample. Results were expressed as mean values with standard deviation. DMRT (Duncan Multiple Range Test) was performed to evaluate the significance of difference between mean values at the level of $5 \%$.

\subsection{Results and Discussion}

The $\mathrm{pH}$ value of honey nut drink has shown in the figure (2) under storage. The range of pH values of honey nut drink was 3.5 to 3.9 during storage. Highest $\mathrm{pH}$ value found in product 1 and lowest in product 3. This value is comparable with the work of Reddy et al., [15] who reporte d the different fruit drink's $\mathrm{pH}$ varied from 2.57 to 3.68 . Our obtained $\mathrm{pH}$ value is lowest as compare to the commercial fruit drink was 4.2 found by Champagne and Gardner [16]. 
Tenuta et al., [17] reported that, the cola-based soft drink possesses $\mathrm{pH}$ about 5.9. A drink developed with medicinal plant (Polygonatun sibiricum, Ophiopogonis radix, Lycii fructus, Schizandriae frutcus) pH was 3.3 [18]. Kausar et al., [19] reported that, the pH value in cucumber-melon drink was 4.89. The variation of $\mathrm{pH}$ value in drink might be due to the acidity content in drink. Because $\mathrm{pH}$ of the product depend on acidity of the product. The $\mathrm{pH}$ increase with increase of acidity. Similar trend was found with all products during the storage period.

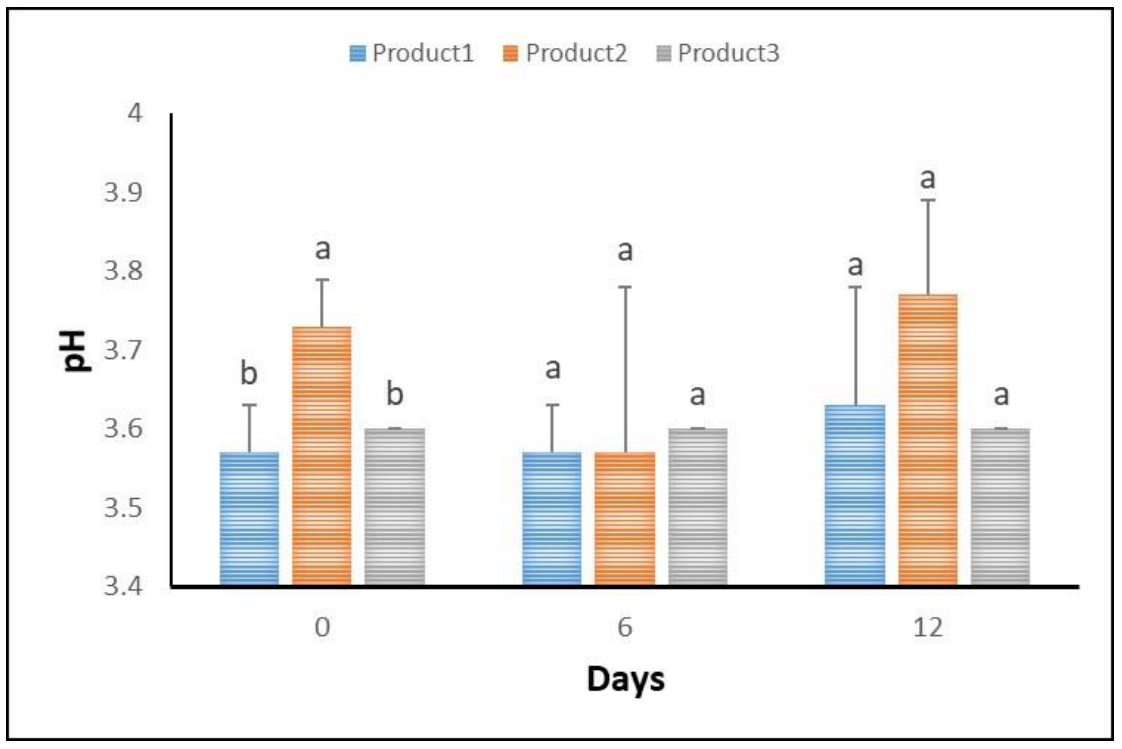

a-b Means followed by different letter of alphabets in bar are significantly different within the product in same day $(\mathrm{p} \leq 0.05)$

Figure 2: $\mathrm{pH}$ value of honey nut drink during storage

The brix $\%$ of honey nut drink are shown in the figure (3) during the storage. The brix \% in honey nut drink ranged from 7 to 13 . Product 1 retained the higher brix $\%$ and lower in product 3 followed by product 2 which were significantly different $(\mathrm{p} \leq 0.05)$ one another. As can see in the figure during the entire storage period brix \% unchanged.

However, our obtained value is lower than the work of Kausar et al., [19] who found that, the TSS percentage of cucumber drink was 15.49-16.09\% during the storage period. The mandarin (Citrus reticulata) diet drink retained the TSS percentage about 18\% [20]. According to Board and Woods [21], apple juice drink contained 8-14\% total soluble solid. Vieira et al., [22] reported that, different brands of orange soft drinks contained $9.88 \%$ brix. The variation of brix \% may be in the products depends on the addition of solid content present in the products.

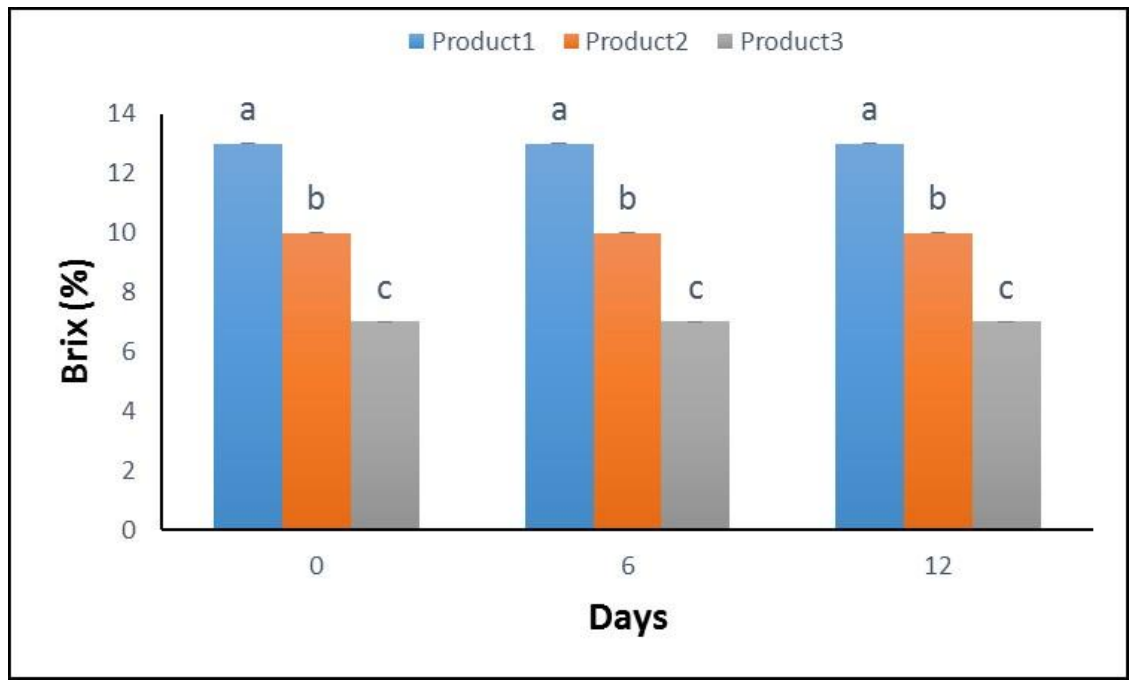

a-c Means followed by different letter of alphabets in bar are significantly different within the product in same day $(\mathrm{p} \leq 0.05)$

Figure 3: Brix \% of honey nut drink during storage

The figure (4) shows the acidity percentage of honey nut drink during storage. The acidity of honey nut drink ranged from 0.16 to $0.32 \%$ under storage period. In the very beginning ( 0 day) highest acidity found in product 1 and lowest in product 3.

After increase storage period acidity was increased. Our obtained values of acidity are lower with the work Kausar et al., [19] who found the acidity in cucumber-melon drink was $0.44 \%$. The mandarin (Citrus reticulata) diet drink retained the acidity about $0.51 \%$ [20]. High acid may be due to production of acetic acid and lactic acid during storage [19]. Increasing the acidity of the drink might be affect the taste of drink that's why sensory profile taste also decrease with the increase the acidity. 


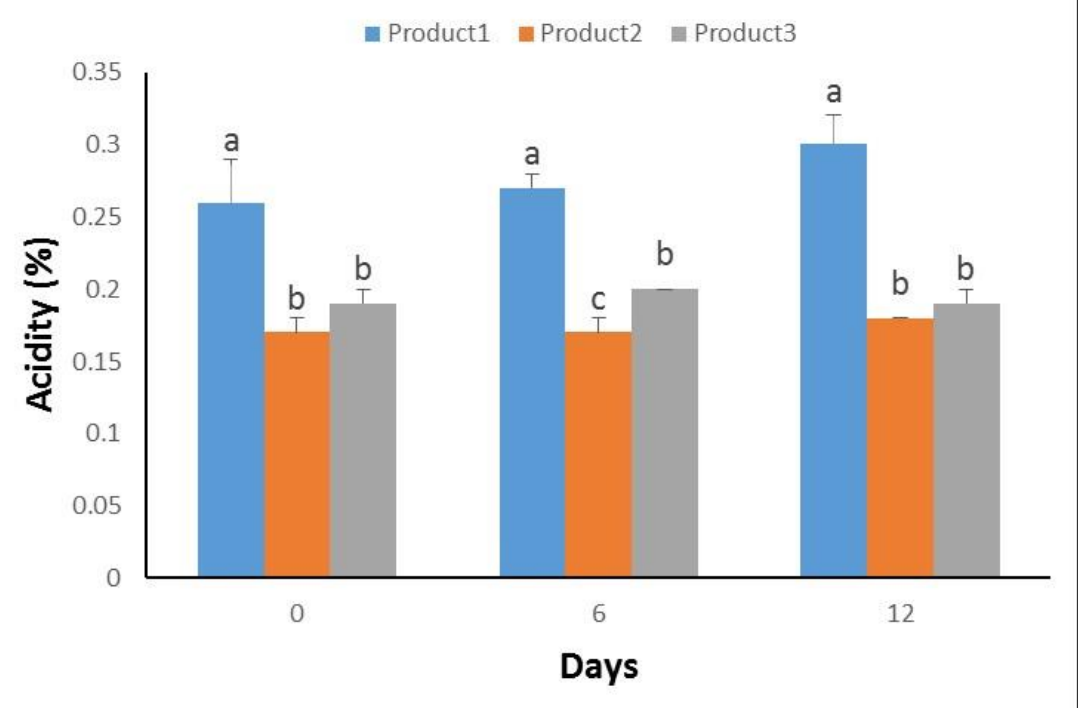

a-c Means followed by different letter of alphabets in bar are significantly different within the product in same day $(\mathrm{p} \leq 0.05)$

Figure 4: Acidity \% of honey nut drink during storage.

The figure (5) has shown the brix acid ratio during storage period. Brix acid ratio is a best indicator for measuring relative sweeteners or tartness of the product. The higher the brix in relation to acid contents of the drink then it means higher will be the ratio of sugars and sweeter the taste. Similarly lower the brix in relation to acidity of the drink, the lower the ratio of sugars and product will be sour in taste. The range of brix acid ratio among the products was 35.00 to 59.99 under storage. Highest value found in product 2 and lowest in product 1 . Our obtained values was higher with the work of Ahmed et al., [20] who found brix acid ratio in Mandarin (Citrus Reticulata) diet drink was 26.81. The variation in brix acid ratio may be due to presence of higher sucrose present in it or more sourness in samples treated with aspartame.

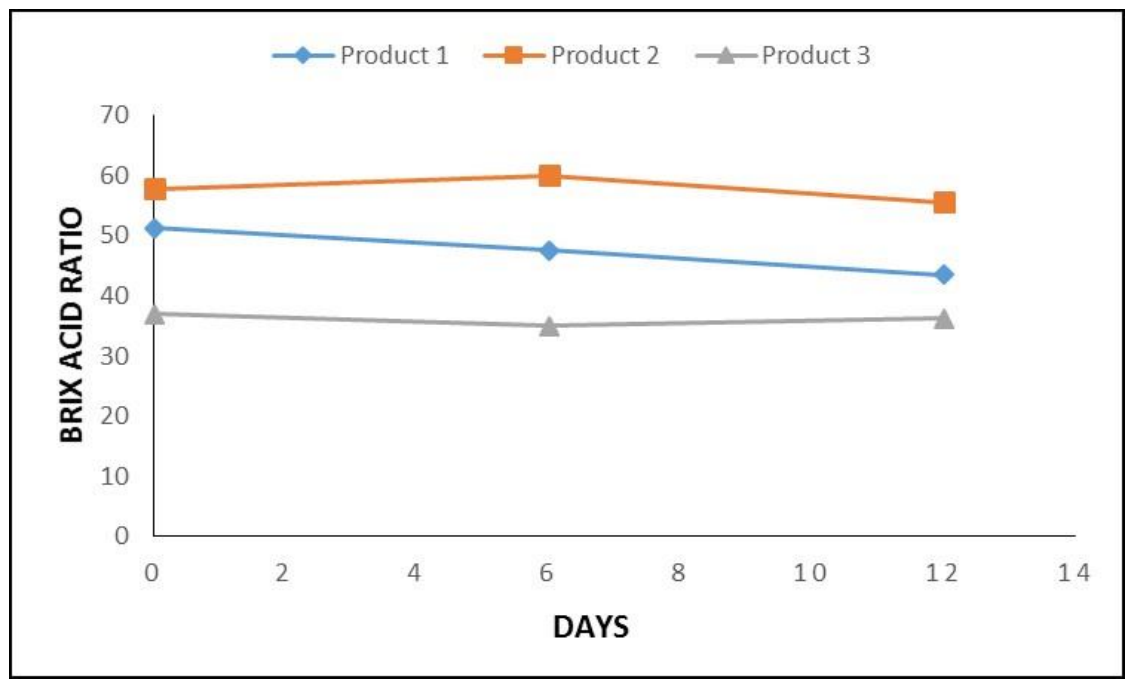

Figure 5: Brix acid ratio of honey nut drink during storage

The sensory characteristics of honey nut drink are shown in Table 2. The sensory profile of honey nut drink was evaluated in terms of color, flavor, taste and overall acceptability after 12 days of storage at a mbient temperature $\left(30 \pm 2^{\circ} \mathrm{C}\right)$. At the very beginning $(0$ day), the sensory score of product 3 shows the highest color, flavor, taste and lowest found in product 1 . The overall acceptability was significantly different $(\mathrm{p} \leq 0.05)$ among the product. After increasing the storage period flavor, taste and overall acceptability was decreased except color which was significantly different among the product. At 12 days of storage, the product 3 retained the higher sensory value as compare to others products.

Table 2: Sensory characteristics of honey nut drink under storage

\begin{tabular}{|l|l|l|l|l|l|}
\hline $\begin{array}{l}\text { Storage } \\
\text { (days) }\end{array}$ & Product & Color & Flavor & Taste & $\begin{array}{l}\text { Overall } \\
\text { acceptability }\end{array}$ \\
\hline \multirow{3}{*}{0} & 1 & $8.40 \pm 0.51^{\mathrm{b}}$ & $7.40 \pm 0.99^{\mathrm{a}}$ & $6.67 \pm 1.11^{\mathrm{b}}$ & $6.40 \pm 1.45^{\mathrm{b}}$ \\
\cline { 2 - 6 } & 2 & $8.00 \pm 0^{\mathrm{c}}$ & $7.33 \pm 0.90^{\mathrm{a}}$ & $7.00 \pm 0^{\mathrm{b}}$ & $7.33 \pm 0.90^{\mathrm{a}}$ \\
\cline { 2 - 6 } & 3 & $9.00 \pm 0^{\mathrm{a}}$ & $7.73 \pm 1.03^{\mathrm{a}}$ & $9.00 \pm 0^{\mathrm{a}}$ & $7.27 \pm 0.70^{\mathrm{a}}$ \\
\hline \multirow{3}{*}{12} & 1 & $8.40 \pm 0.51^{\mathrm{b}}$ & $6.33 \pm 1.54^{\mathrm{b}}$ & $6.53 \pm 0.64^{\mathrm{b}}$ & $6.60 \pm 1.40^{\mathrm{b}}$ \\
\cline { 2 - 6 } & 2 & $8.00 \pm 0^{\mathrm{c}}$ & $6.67 \pm 1.24^{\mathrm{ab}}$ & $7.00 \pm 0.85^{\mathrm{b}}$ & $7.53 \pm 1.06^{\mathrm{a}}$ \\
\cline { 2 - 6 } & 3 & $9.00 \pm 0^{\mathrm{a}}$ & $7.40 \pm 1.30^{\mathrm{a}}$ & $8.20 \pm 0.77^{\mathrm{a}}$ & $7.73 \pm 0.70^{\mathrm{a}}$ \\
\hline \multirow{3}{*}{} & 1 & $8.40 \pm 0.51^{\mathrm{b}}$ & $5.73 \pm 1.58^{\mathrm{a}}$ & $5.40 \pm 0.63^{\mathrm{b}}$ & $5.93 \pm 1.33^{\mathrm{a}}$ \\
\cline { 2 - 6 } & 2 & $8.00 \pm 0^{\mathrm{c}}$ & $5.73 \pm 1.39^{\mathrm{a}}$ & $5.67 \pm 0.72^{\mathrm{ab}}$ & $6.00 \pm 1.36^{\mathrm{a}}$ \\
\cline { 2 - 6 } & 3 & $9.00 \pm 0^{\mathrm{a}}$ & $6.53 \pm 1.60^{\mathrm{a}}$ & $6.13 \pm 1.13^{\mathrm{a}}$ & $6.60 \pm 1.18^{\mathrm{a}}$ \\
\hline
\end{tabular}




\subsection{Conclusion}

In this study, quality parameters like $\mathrm{pH}$, brix, acidity, brix acid ratio and sensory characteristics of formulated honey nut drink were investigated under 12 days of storage at ambient temperature. The $\mathrm{pH}$ values varied from 3.5 to 3.9 during storage. The brix found in three different products ranged from 7 to $13 \%$. The acidity possesses during the entire storage period between 0.16 to $0.32 \%$. The brix acid ratio higher found in product 2 (59.99) and lower in product 3 (35.0) under storage. The sensory profile of three different formulation was evaluated in terms of color, flavor, taste and overall acceptability. Among the three-products formulation product 1 retained better quality followed by product 3 and product 2 considering pH, brix and acidity percentage although after increasing time of storage their value also increased. The sensory profile of product 3 found in much better score followed by the product 1 and product 2 which are significantly different $(\mathrm{p} \leq 0.05)$. In conclusion, commercial purpose both formulation of product 1 and product 3 could be produced.

\subsection{Acknowledgements}

Authors thankful to all faculty members and office staff of the department of Food Engineering, North Pacific International University of Bangladesh (NPIUB), Manikganj and special thanks to Ruhani Consumer \& Beverage Limited, Bangladesh for their financial supports.

\subsection{References}

[1] A. Angelov, V. Gotcheva, R. Kuncheva, and T. Hristozova, “Development of a new oat-based probiotic drink”, Int. J. Food Microbiol., 112, Pp. 75-80, 2006.

[2] C.E. Manyi-Loh, A.M. Clarke, and R.N. Ndip, "An overview of honey: Therapeutic properties and contribution in nutrition and human health-review", Afr. J. Microbiol. Res., 5, Pp. 844-852, 2011.

[3] O. Escuredo, M. Míguez, M. Fernández-González, C.M. Seijo, "Nutritional value and antioxidant activity of honeys produced in a European Atlantic area", Food Chem., 138, Pp. 851-856, 2013.

[4] S. Noori, S. Faiza, A. Mohammed, A. Amjed, Y.S. Khelod, and A.A.L.G. Ahmad, "Effects of natural hon ey on polymicrobial culture of various human pathogens", Arch. Med. Sci., 10, Pp. 246-250, 2014.

[5] J.M. Alvarez-Suarez, F. Giampieri, M. Battino, "Honey as a source of dietary antioxidants: Structures, bioavailability and evidence of protective effects against human chronic diseases”, Curr. Med. Chem., 20, Pp. 621-638, 2013.

[6] D. Cianciosi, T. Forbes-Hernández, S. Afrin, M. Gasparrini, P. Reboredo-Rodriguez, P. Manna, M. Battino, "Phenolic Compounds in Honey and Their Associated Health Benefits: A Review", Molecules, 3, Pp. 1-20, 2018.

[7] R. Segura, C. Javierre, M.A. Lizarraga, and E. Ros, “Other relevant components of nuts, phytosterols, folate and minerals”, Br. J. Nutr., 96, Pp. S36-S44, 2006.

[8] R. Blomhoff, M.H. Carlsen, A. L. Frost, and D.R. Jr. Jacobs, “Health benefits of nuts, potential role of antioxidants”, Br. J. Nutr., 96, Pp. S52-S60, 2006.

[9] E. Ros, "Health Benefits of Nut Consumption-review”, Nutrients, 2, Pp. 652-682, 2010.

[10] S. Verma, "Development and quality evaluation of selected honey-based food products", PhD thesis, Department of Home Science, Aligarh Muslim University, India, Pp. 1-200, 2009.

[11] O. Stanislav, and M. Irina, "Nut beer as a functional drink”, Modern Technol.Food Indus., Pp. 38-40, 2012.

[12] B. Oliete, M. Gómez, V. Pando, E. Fernández-Fernández, P.A. Caballero, and F. Ronda, "Effect of Nut Paste Enrichment on Physical Characteristics and Consumer Acceptability of Bread", Food Sci. Technol. Int., 14, Pp. 259-269, 2008.

[13] T.A. Teka, "Analysis of the effect of maturity stage on the postharvest Biochemical quality characteristics of tomato (lycopersicon esculentum mill.) Fruit”, Int. Res. J. Pharm. App. Sci., 3, Pp. 180-186, 2013.

[14] M.C. Roy, M. Alam, A. Saeid, B.C. Das, M.B. Mia, M.A. Rahman, M. Ahmed, "Extraction and characterization of pectin from pomelo peel and its impact on nutritional properties of carrot jam during storage”, J. Food Process. Preserv., 42, 2018. e13411. doi:10.1111/jfpp.13411

[15] A. Reddy, D.F. Norris, S.S. Momeni, B. Waldo, and J.D. Ruby, “The pH of beverages in the United States”, J. Am. Dent. Assoc., 147, Pp. 255-263, 2016.

[16] C.P. Champagne, and N.J. Gardner, "Effect of storage in a fruit drink on subsequent survival of probiotic lactobacilli to gastro-intestinal stresses", Food Res. Int., 41, Pp. 539-543, 2008.

[17] L.M.A. Tenuta, C.E. Fernández, A.C.S. Brandão, and J.A. Cury, “Titratable acidity of beverages influences salivary pH recovery”, Braz. Oral Res., 29, Pp. $1-6,2015$.

[18] S.H. Park, H.S. Hwang, and J.H. Han, "Development of drink from composition with medicinal plants and evaluation of its physiological fu nction", Korean J. Nutr., 37, Pp. 364-372, 2004.

[19] H. Kausar, S. Sa eed, M.M. Ahmad, A. Salam, “Studies on the development and storage stability of cucumber-melon functional drink", J. Agr. Res., 50, Pp. 239-248, 2012.

[20] M. Ahmed, A. Ahmad, Z.A. Chatha, and S.M.R. Dilshad, "Studies on preparation of ready to serve mandarin (citrus reticulata) diet drink", Pak. J. Agri. Sci., 45, Pp. 470-476, 2008.

[21] P.W. Board, and H.J. Woods, “Compositional variations and sensory acceptability of apple juice drink”, Int. J. Food Sci. Tech., 18 , Pp. 763 -769, 1983.

[22] S.M. Vieira, K.H. Theodoro, and M.B.A. Glória, "Profile and levels of bioactive amines in orange juice and orange soft drink", Food Chem., 100, Pp. 895$899,2007$. 